\title{
PENDEKATAN DIAGNOSIS DAN TATALAKSANA GANGGUAN MOOD PADA USIA LANJUT
}

\author{
Huwainan Nisa Nasution*, Hadiq Firdausi** \\ *Bagian Ilmu Penyakit Dalam Fakultas Kedokteran \\ Universitas Muhammadiyah Sumatera Utara, \\ ** Geriatry Division Departemen Ilmu Penyakit Dalam Fakultas Kedokteran \\ Universitas Airlangga \\ Email: huwainannisa@umsu.ac.id
}

\begin{abstract}
ABSTRAK
Gangguan mood rentan diderita para penderita berusia lanjut. Statistik menunjukkan, terjadi peningkatan presentasi gangguan ini terutama pada penduduk lanjut usia. Hal ini kemungkinan disebabkan oleh gejala post power syndrome yang menyebabkan para lansia menjadi stres dan depresi. Penyebab lainnya yang dapat mencetuskan adalah penyakit komorbid yang menyertai kemudian menimbulkan pergantian mood yang cepat. Penyakit diabetes, tekanan darah tinggi, dan jantung koroner misalnya, diduga menyebabkan penderita merasa hilang kekuatan, kesulitan menyesuaikan diri, hingga akhirnya depresi. Kejadian bunuh diri pada usia lanjut yang mengalami gangguan mood juga dapat terjadi hampir setiap hari. Pentingnya deteksi dan diagnosis sejak dini merupakan hal yang penting demi mendapatkan terapi lebih dini. Gangguan mood pada usia lanjut bukanlah hal yang natural terkait proses penuaan, melainkan suatu gangguan patologis yang dapat diterapi. Pada tinjauan pusataka ini sumber data diambil dari jurnal nasional, jurnal internasional dan buku teks.
\end{abstract}

Kata kunci: gangguan mood, depresi, manik, usia lanjut, geriatri.

\begin{abstract}
Mood disorders are susceptible to elderly sufferers. Statistics show, there is an increase in the presentation of mood disorder, especially in the elderly population. This is probably caused by the symptoms of post power syndrome which causes the elderly to become stressed and depressed. Other causes that can trigger are comorbid diseases that accompany and then cause rapid mood changes. Diabetes, hypertension, and coronary heart disease, for example, are thought to cause lost of strength, difficulty adjusting, and depression. Suicides in the elderly with mood disorders can also occur almost every day. The importance of early detection and diagnosis is important in order to get early therapy.
\end{abstract}


Mood disorders in elderly are not a natural thing related to the aging process, but a pathological disorder that can be treated. In this review article, data sources were taken from national journals, international journals and textbooks.

Key words: mood disorders, depression, manic, elderly, geriatrics.

\section{PENDAHULUAN}

Pasien usia lanjut yang memiliki umur panjang cenderung memiliki penurunan kualitas hidup dan peningkatan kejadian penyakit. Kejadian penyakit terkait dengan gangguan mood pada usia lanjut menjadi perhatian khusus saat ini. Di Kanada kejadian gangguan mood meningkat dari 5,3\% pada tahun 2003 menjadi 6,3\% pada tahun 2009, 43\% gangguan mood yang terjadi pada tahun 2009 didominasi oleh pasien dengan usia 50 tahun ke atas (Stone et al., 2012). Gangguan mood yang utama mencakup gangguan unipolar (gangguan depresi) dan gangguan bipolar yang mencakup periode manik dan bipolar depresi. Depresi, merupakan gangguan mood yang paling tersering terjadi pada usia lanjut dengan prevalensi $12-45 \%$ pada usia lanjut. Di Amerika, diperkirakan 5 juta dari 31 juta penduduk Amerika yang berusia lebih dari 65 ke atas secara klinis memiliki gejala depresi (Gellis \& McCracken, 2010). Menurut data statistik tahun 2005, kejadian bunuh diri lebih tinggi pada usia lanjut yang depresi dengan rata-rata 1,3 kejadian bunuh diri setiap harinya (Wiese, 2011). Di sisi lain, gangguan bipolar pada orang usia lanjut sebenarnya tidak biasa terjadi dan mungkin merupakan pertanda penyakit dasar lainnya seperti penyakit neurologis, contohnya stroke, tumor otak, dan sebagainya (Stone et al., 2012; Diniz, 2011). Sampai saat ini belum ada data di Indonesia tentang gangguan mood pada usia lanjut.

Gangguan mood pada usia lanjut banyak tidak terindentifikasi dan tidak mendapatkan terapi (Byers et al., 2010; Zalik \& Zalar, 2010). Hal ini dikarenakan gangguan mood pada orang usia lanjut dianggap merupakan suatu proses yang natural terkait proses penuaan dan normal didapati (Zalik \& Zalar, 2010), padahal gangguan mood akan lebih baik bila diberikan terapi (Byers et al., 2010). Apabila tidak diterapi dengan baik, gangguan mood pada usia lanjut dapat meningkatkan kejadian demensia dan meningkatkan morbiditas dan mortalitas (Zalik \& Zalar, 2010). Pada tinjauan pusataka ini penulis bertujuan untuk membahas tentang gangguan mood pada usia lanjut yang datanya bersumber dari jurnal nasional, jurnal internasional dan buku teks. 
TINJAUAN PUSTAKA

\section{Definisi dan Klasifikasi}

Menurut American Psychiactric Association, gangguan mood didefinisikan sebagai disregulasi pervasif dari suasana perasaan dan aktivitas psikomotor yang berhubungan dengan gangguan terkait bioritmik dan kognitif. Gangguan mood pada umumnya dibagi menjadi dua, yaitu gangguan unipolar dan gangguan bipolar. Pasien diklasifikasikan sebagai gangguan unipolar dan gangguan bipolar. Gangguan unipolar atau gangguan depresi adalah gangguan fungsional kesehatan mental yang berhubungan dengan beban penyakit yang berat sehingga berdampak pada pasien, keluarga, komunitas dan juga ekonomi (Weise, 2011; Gellis \& McCracken, 2010). Gangguan bipolar merupakan gangguan mood dimana pasien memiliki baik periode gangguan depresi maupun gangguan manik (Aziz et al., 2006).

\section{Patofisiologi}

Pada abad ke-20 diketahui bahwa ketidakseimbangan neurokimia menjadi penyebab patofisiologi dari gangguan mood. Ketidakseimbangan neurokimia yang meliputi sintesis dan sekresi dari norepinefrin dan serotonin menjadi dasar dari penyebab gangguan depresi. Penelitian terbaru menemukan bahwa pasien dengan gangguan depresi memiliki kadar norepinefrin yang rendah. Kemudian penelitian selanjutnya berkembang dan menemukan bahwa terdapat gangguan dari fungsi monoamine sentral, defisiensi neurotransmiter dimediasi oleh serotonin (5-HT, 5-hydroxytryptamin), norepinefrin dan dopamin. Sel tubuh serotonin (serotonin's cell bodies) terdapat pada midbrain raphe dan aksonnya diproyeksikan ke korteks frontal yang memiliki fungsi regulasi untuk mood, serta ganglia basalis terutama area limbik merupakan area untuk modulasi emosi, terutama kecemasan. Proyeksi serotoninergik juga sampai hingga hipotalamus yang merupakan neuron serotonin yang meregulasi untuk makan, nafsu makan, berat badan, nafsu seksual dan siklus tidur. Neuron norepinefrin yang diproyeksikan ke korteks frontalis meregulasi mood, yang diproyeksikan ke hipotalamus limbik meregulasi makan, nafsu makan, berat badan dan nafsu seksual. Selain itu, norepinefrin juga dapat diproyeksikan ke korteks frontalis meregulasi kognitif dan perhatian, ke serebellum memodulasi pergerakan motorik. Monoamine memiliki fungsi yang luas seperti pengaturan tidur, kewaspadaan, nafsu makan, motivasi, aktivitas motorik (Kharade et al., 2010). 
Pendekatan Diagnosis Gangguan

\section{Unipolar (Gangguan Depresi)}

Gangguan unipolar (gangguan depresi) memiliki gejala penurunan mood, kehilangan ketertarikan beraktivitas, tenaga dan konsentrasi, gangguan tidur dan nafsu makan serta peningkatan masalah kesehatan (Weise, 2011). Menurut Diagnostic and Statistical Manual of Mental Disorders Fifth Edition (DSM-V) yang ditunjukkan pada tabel 1, kriteria diagnostik depresi meliputi adanya kesedihan atau anhedonia dengan total lima atau lebih gejala selama 2 minggu (Taylor, 2015).

Geriatric Depression Scale (GDS) dipakai untuk mendiagnosis depresi pada orang usia lanjut (Cong et al., 2015). Alat ukur ini mempunyai sensitivitas $92 \%$ dan spesifisitas $89 \%$.
Apabila hasil skor 0-4 dikategorikan normal, hasil skor 5-8 dikategorikan depresi ringan, hasil skor 9-10 dikategorikan depresi sedang dan hasil skor 12-15 dikategorikan depresi berat (Greenberg, 2012).

Alat ukur lainnya yang secara luas digunakan adalah Hamilton Depression Rating Scale (HDRS). HDRS dikembangkan untuk pasien rawat jalan, dimana dibutuhkan waktu 15-20 menit untuk menyelesaikan wawancara menggunakan alat ukur ini. Menurut Kroenke dan Spitzer, untuk mendiagnosis depresi pada orang usia lanjut dapat juga menggunakan The Patient Health Questionnaire 9 (PHQ-9) sebagai alat ukur tervalidasi dengan sensitivitas $88 \%$ dan spesifisitas $88 \%$ (Taylor, 2015).

Tabel 1 - Kriteria Diagnosis Gangguan Depresi Menurut DSM-V

Kriteria Diagnosis Gangguan Depresi Menurut DSM-V

Lima atau lebih dari gejala berikut yang ditemukan setiap hari selama 2 minggu:

Gejala utama ( $\geq 1$ untuk diagnosis)

Mood depresi hampir setiap hari

Anhedonia atau penurunan ketertarikan atau kesediaan untuk melakukan hampir

seluruh aktivitas

Gejala tambahan

Penurunan berat badan yang signifikan atau meningkatan atau menurunan dari

nafsu makan

Insomnia atau hipersomnia

Agitasi psikomotor atau retardasi

Lelah atau penurunan tenaga

Perasaan tidak berguna atau perasaan bersalah yang tidak tepat 
Kehilangan kemampuan untuk berpikir atau berkonsentrasi, atau bimbang

Pengulangan ide untuk meninggal dunia atau bunuh diri

Sumber: Taylor, 2012

\section{Pendekatan Diagnosis Gangguan Bipolar}

Pada gangguan bipolar terdapat perubahan suasana hati yang dramatis tinggi, atau marah menjadi sedih dan putus asa. Periode tertinggi dan terendah disebut periode mania akut dan periode bipolar depresi. Gejala dan diagnosis periode bipolar depresi sama dengan gangguan unipolar (gangguan depresi). Sedangkan periode manik akut dikarakteristikkan adanya fluktuasi perilaku yang menyimpang (misalnya banyak bicara, bicara keras, egomanik, paranoid dan tidak taat aturan), sekurangnya selama 1 minggu (Diniz, 2011). Kemudian dilakukan pemeriksaan lanjutan dan evaluasi diagnosis diferensial termasuk adanya kondisi medis yang sedang dalam pengobatan yang dapat berkontribusi terhadap adanya gejala manik/depresi dan menjadi data dasar respon terapi dan pemantauan efek samping obat. Pemeriksaan laboratorium seperti panel metabolik lengkap, pemeriksaan darah lengkap, fungsi tiroid, penapisan toksikologi dan pemeriksaan spesifik lain sesuai dengan hasil anamnesis, pemeriksaan fisik dan pemeriksaan neurologis. Pemeriksaan radiologi dilakukan untuk mengetahui adanya kelainan pada serebrovaskular, yang diikuti dengan pemeriksaan elektroensefalogram dan pungsi lumbal bila dibutuhkan (Sajatovic \& Chen, 2011).

Diagnosis gangguan manik akut dapat menggunakan Young Mania Rating Scale (YMRS) yang terdiri dari 11 skala penilain klinis yang dirancang untuk menilai keparahan dan respon terhadap pengobatan gejala manik. Alat ukur ini digunakan sebagai gold standar secara luas baik untuk kepentingan klinis maupun penelitian. Informasi untuk skor diperoleh dari gejala subjektif pasien dilaporkan selama 48 jam sebelumnya dan dari observasi klinis selama wawancara. Namun, YMRS tidak menilai gejala depresi bersamaan dan harus dinilai dengan skala penilaian depresi lainnya seperti dijelaskan sebelumnya. Bila hasil skor sama dengan atau di atas 14, maka pasien dinyatakan mengalami gangguan manik (Sajatovic \& Chen, 2011).

\section{Tatalaksana Gangguan Unipolar (Gangguan Depresi)}

Tatalaksana depresi pada orang usia lanjut meliputi farmakoterapi dan non-farmakoterapi (Weise, 2011). Target 
terapi yang dituju adalah mencegah adanya remisi dari gejala depresi selama pengobatan akut, kemudian mempertahankan respon antidepresan selama fase pemeliharaan (Diniz et al., 2011). Depresi pada usia lanjut dapat berhasil diterapi diantaranya melalui tatalaksana (Weise, 2011):

1. Farmakoterapi

Saat memilih antidepresan, hal yang penting untuk diperhatikan adalah pasien usia lanjut memiliki respon terapi yang bervariasi, tipe depresi yang berbeda-beda, pasien dengan masalah medis lainnya, pasien dengan pengobatan lainnya dan potensi pasien untuk mengalami overdosis. Antidepresan yang efektif adalah obat yang mampu mengobati gejala depresi, tetapi tidak memperburuk masalah medis lain dan tidak menyebabkan efek samping obat (Wiese, 2011).

Selective serotonin reuptake inhibitors (SSRIs). SSRIs merupakan pilihan utama pada terapi farmakologi dari depresi pada usia lanjut. Golongan ini sama efektifnya dengan antidepresan golongan tricyclic, namun lebih aman dan bertoleransi dengan baik pada pasien dengan gangguan kardiovaskular (Taylor, 2015; Diniz, 2011; Wiese, 2011). Golongan SSRIs yang paling aman digunakan adalah citalopram dan sertraline, hal ini dikarenakan memiliki potensi interaksi obat yang paling rendah berdasarkan interaksi pada sitokrom P-450. Fluoxetine, paroxetine dan fluvoxamine memiliki risiko yang tinggi dalam interaksi obat (Wiese, 2011). Efek samping yang ditimbulkan golongan SSRIs meliputi mual, mulut kering, insomnia, somnolen, agitasi, diare, peningkatan keringat dan yang jarang terjadi, disfungsi seksual (Taylor, 2015; Wiese, 2011).

Selective norepinephrine reuptake inhibitor (SNRI). Golongan SNRI seperti venlafaxine, mirtazapine dan bupropion memiliki profil keamanan yang baik sehubungan dengan interaksi obat pada usia lanjut. Golongan SNRI memiliki efek antikolinergik yang lebih rendah dan bertoleransi baik pada pasien dengan penyakit kardiovaskular (Wiese, 2011).

Antidepresan trycyclic. Antidepresan trycyclic tidak lagi menjadi pilihan pertama antidepresan pada usia lanjut dikarenakan potensi efek sampingnya yang tinggi meliputi hipotensi postural, yang dapat memicu pada kejadian jatuh dan fraktur, konduksi jantung yang abnormal dan efek antikolinergik yang meliputi delirium, retensi urin, mulut kering dan konstipasi. Apabila 
golongan ini menjadi pilihan yang kedua, maka dapat dipertimbangkan pemberian nortriptyline dan desipramine yang memiliki efek antikolinergik paling minimal (Wiese, 2011).

Tabel 2 - Pilihan Antidepresan pada Usia Lanjut

\begin{tabular}{cccc}
\hline Nama Obat & $\begin{array}{c}\text { Dosis Awal } \\
(\mathbf{m g} / \mathbf{h a r i})\end{array}$ & $\begin{array}{c}\text { Rerata } \\
\text { Dosis (mg) }\end{array}$ & $\begin{array}{c}\text { Rekomendasi } \\
\text { Dosis Maksimal } \\
(\mathbf{m g})\end{array}$ \\
\hline SSRIs & 10 & $20-40$ & 40 \\
Citalopram & 5 & $10-20$ & 20 \\
Escitalopram & 25 & $50-150$ & 200 \\
Sertraline & & & 150,2 kali sehari \\
Agen Lainnya & 100 & 100,2 kali sehari & 45 \\
Buproprion & 15 & $30-45$ & 300,2 kali sehari \\
Mirtazapine & 150 & $150-300,2$ kali sehari & 300 \\
Moclobemide & 37,5 & $75-225$ & 300 \\
Venlafaxine & & & 200 \\
Trycyclic & $10-25$ & $50-150$ & $30-100$ \\
Desipramine & $10-25$ & 400 & \\
Nortriptyline & &
\end{tabular}

Sumber: Wiese, 2011

Untuk dosis antidepresan pada orang usia lanjut, dapat dimulai dengan setengah dosis dewasa untuk meminimalisir efek samping obat. Hal ini mengingat risiko efek samping obat yang meningkat pada orang usia lanjut terkait metabolisme di hepar yang menurun. Apabila tidak didapati perbaikan setelah 2 sampai 4 minggu, maka dosis dapat ditingkatkan hingga terjadi perbaikan klinis. Apabila dalam 8 minggu pasien sudah dalam dosis maksimal namun tidak menunjukkan perbaikan, maka dapat dipertimbangkan untuk mengganti antidepresan. Penurunan dosis secara berkala dapat dilakukan sebelum mengganti antidepresan. Penghentian pengobatan secara mendadak akan memicu sindrom withdrawal meliputi anxietas, insomnia dan flu-like symptoms. Umumnya penurunan berkala antidepresan dilakukan selama 7-10 hari (Wiese, 2011). 
2. Non-farmakoterapi

Perubahan gaya hidup. Pasien orang usia lanjut dengan depresi harus dimotivasi untuk meningkatkan aktivitas fisik sebagaimana yang bisa dilakukannya. Aktivitas fisik dengan intensitas sedang mampu menurunkan gejala depresi. Rekomendasi lainnya meliputi perbaikan nutrisi dan meningkatkan motivasi untuk interaksi dan aktivitas sosial. Namun, perubahan gaya hidup akan kurang bermanfaat bila tidak disertai dengan intervensi lainnya, yaitu farmakoterapi, psikoterapi atau keduanya (Taylor, 2015).

Psikoterapi. Psikoterapi merupakan terapi yang efektif untuk depresi pada orang usia lanjut dan dapat dipertimbangkan untuk menjadi pilihan terapi lini pertama tergantung pada tingkat depresi pada pasien. Psikoterapi yang terstandar meliputi fase tatalaksana jangka pendek dengan kunjungan mingguan selama 8-12 minggu. Pasien akan dievaluasi apakah memerlukan terapi jangka panjang atau penurunan jumlah frekuensi setelah dilakukan psikoterapi jangka pendek (Taylor, 2015).

Electroconvulsive therapy (ECT). Penggunaan ECT dapat dipertimbangkan pada pasien dengan ide bunuh diri atau tidak berespon terhadap pengobatan antidepresan yang telah diberikan (Taylor, 2015; Wiese, 2011). ECT tidak dianjurkan pada pasien dengan gangguan kardiovaskular dan penyakit neurologik karena dapat menyebabkan gangguan memori sehubungan dengan ECT (Taylor, 2015).

\section{Tatalaksana Gangguan Bipolar}

Tatalaksana gangguan bipolar dapat meliputi (Sajatovic \& Chen, 2011):

1. Farmakoterapi pada Manik Akut

Golongan obat yang dapat dipakai pada tatalaksana gangguan bipolar periode manik akut adalah golongan mood stabilizer (contohnya divalproex sodium, litium, carbamazepine, lamotrigine, oxcarbazepine, gabapentin, topiramate, zonisamide) dan golongan antipsikotik (contohnya clozapine, risperidone, olanzapine, quetiapine, aripiprazole).

Valproate. Valproate merupakan obat lini pertama yang digunakan pada gangguan bipolar pada dewasa. Beberapa data menunjukkan valproate efektif dan aman digunakan pada orang usia lanjut (Diniz et al., 2011). Efek samping yang jarang terjadi meliputi pankreatitis, hepatotoksik fatal dan 
ensephalopati terutama pasien dengan gangguan siklus urea misalnya pada pasien dengan gangguan ginjal (Sajatovic \& Chen, 2011).

Litium. Litium kemungkinan lebih sedikit dipakai pada usia lanjut dibandingkan dengan valproate dikarenakan banyaknya intoleransi dan komorbiditas medis. Namun, litium dapat dipertimbangkan pada pasien orang usia lanjut dengan manik klasik dan gangguan neurologik minimal (Sajatovic \& Chen, 2011). Pada usia lanjut direkomendasikan untuk pemberian litium dosis rendah. Hal ini dikarenakan pasien usia lanjut lebih mudah untuk menderita toksisitas litium akut terkait dengan penurunan fungsi ginjal, gangguan kardiovaskular dan interaksi obat dengan golongan angiotensinconverting enzym inhibitor, calcium antagonist, thiazide dan loop diuretics, serta obat anti-inflamasi non-steroid.

Carbamazepine. Carbamazepine dapat digunakan sebagai alternatif pengobatan pada manik akut. Carbamazepine bermanfaat pada gangguan bipolar atipikal. Walaupun demikian, belum ada penelitian klinis penggunaan carbamazepine pada usia lanjut (Sajatovic \& Chen, 2011).

Antipsikotik generasi kedua. Penggunaan antipsikotik generasi kedua seperti risperidone, quetiapine dan olanzapine efektif pada pengobatan gangguan manik akut. Antipsikotik ini dapat dipakai tunggal maupun dikombinasi dengan golongan mood stabilizer. Hingga kini hanya clozapine pada antipsikotik generasi kedua yang tidak disetujui untuk digunakan pada tatalaksana gangguan bipolar manik akut (Sajatovic \& Chen, 2011).

2. Farmakoterapi pada Bipolar Depresi Penggunaan antidepresan pada tatalaksana gangguan bipolar masih kontroversi. Litium, lamotrigine, quetiapine dan kombinasi olanzapine/fluoxetine menunjukkan efektivitas dalam pengobatan bipolar depresi pada populasi di berbagai usia. Namun demikian, risiko efek metabolik tinggi pada olanzapine, dan kemungkinan memberat pada usia lanjut dikarenakan kecenderungan orang usia lanjut mengalami pertambahan berat badan, sindrom metabolik dan diabetes (Sajatovic \& Chen, 2011).

3. Non-farmakoterapi

Electroconvulsive Therapy (ECT). ECT biasanya dipertimbangkan pada pasien yang memerlukan respon 
klinis dan definitif yang cepat, contohnya pada pasien dengan gangguan bipolar disertai ide bunuh diri atau risiko membunuh orang lain, dengan gejala katatonik, tahap psikotik atau agitasi, atau tahap rentan secara medis (Sajatovic \& Chen, 2011).

Intervensi Psikososial. Intervensi psikososial memiliki peran penting dalam meningkatkan keluaran jangka pendek meliputi menurunan gejala dan stres, termasuk keluaran jangka panjang yaitu kepatuhan pengobatan, pencegahan relaps, pemulihan secara fungsional dan menurunkan komorbiditas medis (Sajatovic \& Chen, 2011).

\section{PEMBAHASAN}

Gangguan bipolar merupakan gangguan biologis pada otak yang secara signifikan memicu gangguan suasana perasaan dan psikosis. Diagnosis gangguan depresi dilakukan menurut DSM-V dan gangguan manik akut dapat menggunakan Young Mania Rating Scale (YMRS) (Sajatovic \& Chen, 2011; Taylor, 2015). Gangguan mood dapat ditatalaksana dengan non-farmakologi dan farmakologi. Gangguan depresi dapat diterapi dengan golongan obat SSRIs, SNRI dan golongan trycyclic (Wiese, 2011). Sedangkan gangguan manik akut dapat diterapi dengan golongan mood stabilizer (Sajatovic \& Chen, 2011).

Prognosis dari depresi pada usia lanjut biasanya buruk. Sebuah penelitian meta-analisis pada pasien depresi selama 24 bulan diestimasi hanya 33\% yang membaik, 33\% tetap menderita depresi, $13 \%$ perlu perawatan di rumah sakit dan $21 \%$ meninggal dunia (Gellis \& McCracken, 2010). Data statistik menunjukkan kejadian bunuh diri lebih tinggi 2 kali pada orang usia lanjut dengan depresi dibandingkan populasi umum dengan rata-rata 1,3 kejadian bunuh diri setiap harinya di Kanada (Weise, 2011; Gellis \& McCracken, 2010). Adapun faktor prediktor yang memperburuk prognosis gangguan depresi pada usia lanjut yaitu kepatuhan pengobatan yang buruk sehingga dapat memicu kondisi penyakit medis yang kronis, kecenderungan bunuh diri, penyembuhan yang lama dari penyakit dan paska operasi, penyakit penyerta lainnya dan kecenderungan untuk polifarmasi pada usia lanjut (Taylor, 2015; Gellis \& McCracken, 2010). Pada tahun 2005, kejadian bunuh diri pada orang usia lanjut pria hampir dua kali lebih banyak. Bunuh diri pada orang usia lanjut pria biasanya menggunakan senjata api dan karena gantung diri, sedangkan pada orang usia lanjut wanita lebih sering karena meminum atau 
memakan racun dan gantung diri (Weise, 2011).

Sedangkan prognosis gangguan bipolar pada usia lanjut lebih buruk daripada pasien dewasa muda. Hal ini dikarenakan pada pasien usia lanjut, pengobatan biasanya tidak tuntas, terjadi episode berulang dari penyakit dan mortalitas yang lebih tinggi, serta peningkatan kejadian bunuh diri.

\section{KESIMPULAN}

Gangguan mood merupakan salah satu kejadian penyakit yang prevalensinya terus meningkat pada usia lanjut. Gangguan mood pada usia lanjut banyak tidak terdiagnosis dan tidak diterapi. Hal ini dikarenakan gangguan mood pada usia lanjut dipercaya merupakan suatu yang natural menyangkut suatu proses penuaan dan kejadian yang normal pada orang usia lanjut. Gangguan mood pada umumnya dibagi menjadi dua, yaitu gangguan unipolar dan gangguan bipolar. Pasien diklasifikasikan sebagai gangguan unipolar apabila hanya ada periode gangguan depresi saja dan diklasifikasikan sebagai gangguan bipolar apabila terdapat periode gangguan depresi dan gangguan manik. Gangguan mood pada orang usia lanjut dapat disembuhkan dengan pengobatan baik secara farmakoterapi maupun nonfarmakoterapi. Diharapkan tinjauan pustaka ini bisa menjadi bahan untuk pembahasan lebih lanjut tentang gangguan mood pada usia lanjut terutama terfokus pada aspek farmakologi obat dan interaksi obat pada usia lanjut.

\section{DAFTAR PUSTAKA}

Byers AL, Yaffe K, Covinsky KE, Friedman MB, Bruce ML, 2010, High Occurrence of Mood and Axiety Disorders Among Older Adults. Arch Gen Psychiatry, 67 (5): 489-496.

Colasanti V, Marianetti M, Micacchi F, Amabile GA, Mina C, 2010, Test for The Evaluation of Depression in The Elderly: A Systematic Review. Archives of Gerontology and Geriatrics, 50: 227-30.

Cong L, Dou P, Chen D, 2015, Depression and Associated Factors in The Elderly Cadres in Fuzhou, China: A CommunityBased Study. International Journal of Gerontology.

Diniz BS, Nunes PV, Mochardo-Vieira R, Forlenza OV, 2011, Current Pharmacological Approches and Perspective in The Treatment of Geriatric Mood Disorders. Current Opinion in Pcychiatry, 24: 473-77.

Gellis ZD, McCracken SG, 2010, Chapter 3 Depressive Disorders in Older Adults. National Center for Gerontological Sosial Work Education, 1-20.

Kharade SM, Gumate DS, Naikwade NS, 2010, A Review: Hypothesis of Depression and Role of Antidepressant Drugs. International Journal pf Pharmacy and Pharmaceutical Sciences, 2(4): 3-6.

Sajatovic M, Chen P, 2011, Geriatric Bipolar Disorder. The Psychiatric Clinics North America, 34: 31933.

Stone RC, Meisner BA, Baker J, 2012, Mood Disorders Among Older 
Adults Participating in Individual and Group Active Enviroments: "Me" versus "Us" or Both?. Journal of Aging Research Volume 2012 Article ID 727983, 7.

Wiese BS, 2011, Geriatric Depression: The Use of Antidepressants in The Danubina, 25(11): 40-48.
Elderly. BC Medical Journal, 53(7).

Zalik E, Zalar B, 2010, Differences in Mood Between Elderly Persons Living in Different Residential Evironments in Slovenia. Psychiatria 